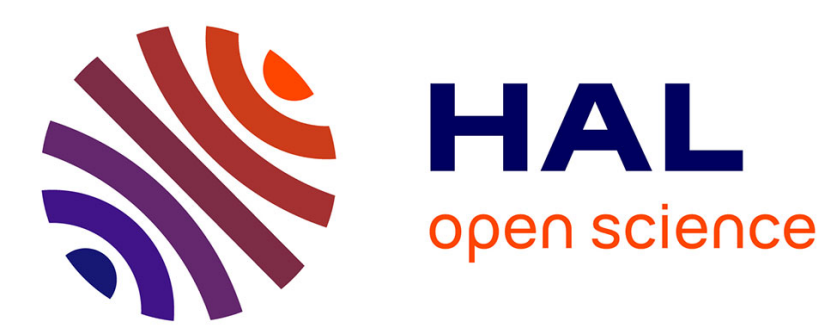

\title{
Models cannot predict future outbreaks: A/H1N1 virus, the paradigm
}

\author{
Antoine Nougairède, Rémi N. Charrel, Didier Raoult
}

\section{To cite this version:}

Antoine Nougairède, Rémi N. Charrel, Didier Raoult. Models cannot predict future outbreaks: A/H1N1 virus, the paradigm. European Journal of Epidemiology, 2010, 26 (3), pp.183-186. 10.1007/s10654-010-9533-6 . hal-00651656

\section{HAL Id: hal-00651656 https://hal.science/hal-00651656}

Submitted on 14 Dec 2011

HAL is a multi-disciplinary open access archive for the deposit and dissemination of scientific research documents, whether they are published or not. The documents may come from teaching and research institutions in France or abroad, or from public or private research centers.
L'archive ouverte pluridisciplinaire HAL, est destinée au dépôt et à la diffusion de documents scientifiques de niveau recherche, publiés ou non, émanant des établissements d'enseignement et de recherche français ou étrangers, des laboratoires publics ou privés. 


\section{Models cannot predict future outbreaks: A/H1N1 virus, the paradigm}

$5^{1}$ : Fédération de Microbiologie, Hôpital de la Timone, Assistance Publique-Hôpitaux de 6 Marseille, France.

$7 \quad 2$ : UMR 190 Pathologies Virales Emergentes, Institut de Recherche pour le Développement8 Université de la Méditerranée, Marseille, France.

$9 \quad 3$ : Unité de Recherche sur les Maladies Infectieuses et Tropicales Emergentes UMR CNRS 106236 IRD 3R198, Université de la Méditerranée, Marseille, France.

11

$\S$ : Corresponding author: Unité de Recherche sur les Maladies Infectieuses et Tropicales Emergentes CNRS UMR 6236 - IRD 3R198 Faculté de Médecine, 27, Bd Jean Moulin 13005 MARSEILLE TEL. 0491324480 FAX 0491387772 Email : didier.raoult@gmail.com 


\section{Abstract}

23 Evolution of the industrialized society had led to a risk management policy in many domains.

24 Assessment of health care risk in the case of infectious diseases often includes mathematical

25 models. Results of modelling were used in France to design emergency plans against flu

26 pandemic. We believe that models cannot predict the features of the future outbreaks

27 because the intrinsic properties of an emergent pathogen and the ecosystem in which it is

28 developing are very complex. Of course, prediction of future outbreaks is not possible

29 without using models, but we think that it is an illusion to presently believe that emerging

30 phenomenon can be anticipated by using only prediction from models. The recent pandemic

31 caused by the novel A/H1N1 virus has confirmed the unpredictability of infectious diseases.

32 The rapid evolution in several domains such as antimicrobial therapeutics, vaccine and

33 hygiene conditions make comparison with past pandemics hard. The adherence of

34 populations to prevention measures and immunisation campaigns are unpredictable. In

35 addition, the presentation of pessimistic models is deleterious. They impress governments

36 and provoke fears. There is a striking necessity to develop the number and the capacities of

37 sentinel centres to take and adapt decisions based on timely available scientific information. 
Evolution of society had led to a risk management policy in many domains. The assessment of health care risk in infectious diseases, especially concerning future epidemics, often includes mathematical models which tentatively predict in silico the burden of the future outbreaks such as attack rate, dissemination, morbidity or mortality. Currently, models are designed to run with different scenarios, and probabilistic methods allow testing their performance in a number of situation. But the question asked by physicians, scientists and in fact everyone is "how many people will die, how many will be hospitalized?". Such predictions from models were used in France to design the emergency plan against flu pandemic [1]. We believe that models cannot predict with acceptable accuracy the features of the future outbreaks because the intrinsic properties of an emergent pathogen and the ecosystem in which it is developing are very complex and unstable. Of course, prediction of future outbreaks is not possible without using models, but we think that it is an illusion to presently believe that emerging phenomenon can be anticipated by using only prediction from models. The recent pandemic caused by the novel A/H1N1 virus has confirmed the unpredictability of infectious diseases.

Seasonality of respiratory infections is a well-known phenomenon in temperate regions. Flu has long been associated with cold season, and the word "Influenza" comes from "influenza di freddo" in Italian that means "cold influenced". A marked peak of respiratory infections occurs during cold winter months. Several mechanisms have been proposed to explain it, such as seasonal environmental changes (temperature humidity...), seasonal host-behaviour changes and seasonal changes in host physiology (melatonin, vitamin D...) [2-4]. However there is still no clear understanding of this phenomenon. In contrast, disease seasonality is less defined in tropical regions where a background of influenza cases is observed throughout the year on top of which epidemics occur at intermediate months between the influenza season in temperate countries of the Northern and Southern hemispheres [4]. On the top, none of yet proposed determinants can explain why the four last pandemics of influenza $(1918,1957,1968$, and 2009) did not initiate during the cold season. was recently described in Europe and drastically modified the dynamics of the outbreak [56]. In France and in Sweden, an epidemic of rhinovirus infections occurred after the start of 
school year, and delayed the onset of the A/H1N1 pandemic. We also observed in Marseille that the epidemic of Respiratory Syncytial Virus bronchiolitis, which happens usually just before the seasonal flu epidemic, occurred later in the season, just after that the A/H1N1 pandemic started to decline. In addition interference between several Influenza viruses remains not properly known: at the beginning of the $\mathrm{A} / \mathrm{H} 1 \mathrm{~N} 1$ pandemic, nobody was able to predict whether seasonal influenza strains (H3N2 and H1N1) would still provoke an epidemic wave or not.

In certain groups of population, the presence of cross-reactive antibodies against a new pandemic strain of influenza can heavily affect viral dissemination and therefore impact on the epidemiologic characteristics of the pandemic (total number of cases, age of the cases, number of severe cases, number of deaths, death rate, length of the phenomenon...) and seems unpredictable. The fact that the elderly were partially protected against the novel A/H1N1 [7-9] explains that the novel A/H1N1 virus infected mostly young people. In addition, at-risk groups may not be the same as for seasonal flu. For example, obesity was an undisputable independent risk factor of severity and lethality during the A/H1N1 pandemic [10-11].

The inherent variability of new variants makes predictions difficult. Each pandemic virus has its own intrinsic properties which can evolve during the pandemic period. Then, intrinsic pathogenicity of new pandemic variants appears to be unpredictable. Data experimental derived from animal models must not be directly extrapolated to humans: in the $\mathrm{A} / \mathrm{H} 1 \mathrm{~N} 1$ case, experiences with ferrets predicted a severity of pneumonia intermediate between that due to seasonal virus and the highly pathogenic avian H5N1 virus [12]. But in fact, the fatality rate of the novel A/H1N1 virus was relatively mild.

The novel 2009 H1N1 virus reminded the 1918 pandemic, also caused by a H1N1 virus, despite totally distinct, which was associated with a large number of secondary bacterial co-infection which could explain partially the huge number of deaths [13]. Because of drastically different sanitary conditions nowadays, it is awkward to use the 1918 data as a basis for anticipating the spread, severity, and health consequences of present and future H1N1 pandemics. Currently, the use of antibiotics and anti-pneumococcal vaccines allow to efficiently combat the historically lethal bacterial co-infections. The availability of adapted vaccine and the rapid evolution on several domains such as antiviral therapeutics and 
101 hygiene conditions are likely to play a critical role in the burden of these new pandemic

102 variants as well as the increase of air traffic in their spread. Some models take into account

103 the impact of human interventions such as vaccine/antiviral delivery, isolation of infected

104 patients, school closure, halting air traffic and non-pharmaceutical interventions. Moreover,

105 it remains often difficult to evaluate their real impact even without applying any model. For

106 example, it was only in the late nineties that hand washing indisputably demonstrated,

107 through randomized trials, its efficacy to prevent inter-human transmission in developed

108 countries [14-15]. In 2005, a randomized-trial in Pakistan confirmed it in low-income

109 countries [16]. Furthermore, the efficacy of mask use, largely recommended during A/H1N1

110 pandemic, to prevent respiratory infections is still to be clearly established by randomized

111 trials [17-19]. Thereby, their introduction into models seems very tricky.

112 The vast majority of studies showed that immunization against influenza has a true

113 impact in terms of hospitalization rate, global morbidity, influenza associated mortality as

114 well as global mortality [20-26]. Intriguingly, during the immunisation campaign against the

$115 \mathrm{~A} / \mathrm{H} 1 \mathrm{~N} 1$ pandemic virus, a large proportion of the population was reluctant to accept

116 vaccination in some countries such as France and Germany. Human behaviours often are

117 unpredictable and could vary among countries and vary with time. In France, the negative

118 image provided by the mass media could have contributed to the low uptake of the A/H1N1

119 vaccine. We observed and reported that in public hospitals of Marseille, the nurses were less

120 immunised against the new A/H1N1 pandemic virus than against seasonal flu [27]. Fears of

121 vaccination promoted by anti-immunization lobbies are largely relayed by the media and the

122 doubts induced and amplified by mediatisation persists for a long time, even when scientists

123 have demonstrated that there is no scientific evidence for suspicion. The association

124 between multiple sclerosis and hepatitis $B$ vaccine on one hand [28], and between autism

125 and measles vaccine on the other hand [29] will be standing for many years to come, and

126 any model is able to predict these events. One model can predict the willingness to accept a

127 vaccine only for one specific situation. External factors cannot be included into models

128 because they are often unknown until they appear. In France, the fact that medical

129 information about the A/H1N1 vaccine was delivered and promoted primarily by politicians

130 could have a counterproductive effect. Medical recommendations bypassing the medical

131 system arouse suspicion in the population [27]. 
With hindsight, the recent pandemic reinforces the idea that presentation of

133 pessimistic models mostly based on extrapolated hypotheses is deleterious. They impress

134 governments and provoke fears. In another hand, it has been previously observed that

135 pessimistic hypothesis about bioterrorism based only on speculations led governments to

136 elaborate countermeasure plans with disproportionate measures. The Dark Winter

137 operation, a bio-terrorist attack simulation, resembles movie script more than reality. Fears

138 of a putative H5N1 avian flu pandemic amplified by pessimistic figures based on

139 unsupported prediction constrained governments to implement emergency flu plans. Later

140 on, these plans postulated that the fatality rate will be close to that observed in cases of

$141 \mathrm{~A} / \mathrm{H} 5 \mathrm{~N} 1$ infection. For example, In France the 2009 emergency plan against pandemic flu

142 predicted 91000 to 212000 deaths [1]. But A/H5N1 virus is still an almost pure zoonotic

143 agent with transmission properties drastically distinct from those of the human adapted

$144 \mathrm{H} 1 \mathrm{~N} 1, \mathrm{H} 2 \mathrm{~N} 2$ or H3N2 viruses. During the A/H1N1 pandemic in Marseille, no intermediate

145 measure had been planified between (i) maintaining the organisation and logistics of the

146 public hospital system as it was before the crisis, and (ii) the emergency opening of a 700

147 bed-hospital exclusively dedicated for A/H1N1 infected patients. In the real-life situation,

148 along 10 month pandemic period, more than 2,500 clinical specimens were laboratory-

149 documented: of these patients, around $11 \%$ were hospitalized and used simultaneously less

150 than 50 beds at the peak of the pandemic.

151 In conclusion, infectious diseases remain unpredictable with mathematical models

152 because pathogens and their ecosystem evolve continuously in a very unstable manner. Of

153 course, some models which take into consideration the antiviral/antimicrobial therapies, the

154 vaccines, the sanitary condition and the non-pharmaceutical interventions are useful to

155 anticipate some logistic problems (quantity to purchase...) and can help to prepare the

156 response to the future pandemics but they cannot predict with acceptable accuracy the

157 major features of a future pandemic (number of cases, hospitalization, deaths...). The

158 pessimistic predictions resulting from bioterrorism and the putative avian flu outbreak were

159 published in highly-rated scientific journals. However they were neither supported by

160 indisputable scientific evidence nor confirmed in real-time up to now. They fuelled fears in

161 the population through amplification by the media, causing great concern amongst the

162 public and the politicians. In order to fight future outbreaks and as a complementary 
163 approach of modelling methods, we need to reinforce the network of sentinel centres by

164 increasing their timely detection/diagnostics capacities and by implementing a large variety

165 of technological tools detecting abnormal events. The data from these sentinel centres

166 should not be necessarily exhaustive but they require to produce sufficient amount of data

167 to investigate emergence and epidemic tendencies. Coupled with the fact that data from

168 hospital-based surveillance systems and Google searching tools are easily and timely

169 available, such surveillance method system will not be very costly. Our capacity for analysis

170 and laboratory documentation needs to be increased and better integrated; during a crisis

171 all data must be rapidly shared using communication media such as internet [30]. Rapid

172 communication of research using specific free media such as Promed and 'PloS Currents:

173 Influenza' can also improve the information dissemination. In addition, very early data about

174 a new variant could be incorporate in some models and then produce more accurate

175 predictions. Furthermore, decision process should be based on timely available scientific

176 data to allow decision makers to take real time decision. Precautionary principle should be

177 advantageously replaced by alertness principle.

178

179 
1811 Secrétariat général de la défense nationale (république française). Plan national de

182 prévention et de lutte « pandémie grippale » $n^{\circ}$ 150/sgdn/pse/pps du 20 février 2009. Available: Http://www.Pandemie-grippale.Gouv.Fr/img/pdf/plan_pg_2009.Pdf. Accessed on 2010 nov. 4. 2009

1852 Dowell SF: Seasonal variation in host susceptibility and cycles of certain infectious 186 diseases. Emerg Infect Dis 2001;7:369-374.

1873 Lipsitch M, Viboud C: Influenza seasonality: Lifting the fog. Proc Natl Acad Sci U S 188 A 2009;106:3645-3646.

1894 Lofgren E, Fefferman NH, Naumov YN, Gorski J, Naumova EN: Influenza

190 seasonality: Underlying causes and modeling theories. J Virol 2007;81:5429-5436.

1915 Casalegno JS, Ottmann M, Duchamp MB, Escuret V, Billaud G, Frobert E, Morfin F, 192 Lina B: Rhinoviruses delayed the circulation of the pandemic influenza a (h1n1) 2009 virus in 193 france. Clin Microbiol Infect 2010;16:326-329.

1946 Linde A, Rotzen-Ostlund M, Zweygberg-Wirgart B, Rubinova S, Brytting M: Does 195 viral interference affect spread of influenza? Euro Surveill 2009;14:pii=19354.

1967 Hancock K, Veguilla V, Lu X, Zhong W, Butler EN, Sun H, Liu F, Dong L, DeVos 197 JR, Gargiullo PM, Brammer TL, Cox NJ, Tumpey TM, Katz JM: Cross-reactive antibody 198 responses to the 2009 pandemic h1n1 influenza virus. N Engl J Med 2009;361:1945-1952.

1998 Miller E, Hoschler K, Hardelid P, Stanford E, Andrews N, Zambon M: Incidence of 2002009 pandemic influenza a h1n1 infection in england: A cross-sectional serological study. 201 Lancet 2010;375:1100-1108.

2029 Nougairede A, Ninove L, Zandotti C, Salez N, Mantey K, Resseguier N, Gazin C, 203 Raoult D, Charrel RN, de Lamballerie X: Novel virus influenza a (h1n1sw) in south-eastern 204 france, april-august 2009. PLoS One 2010;5:e9214.

20510 Intensive-care patients with severe novel influenza a (h1n1) virus infection - michigan, 206 june 2009. MMWR Morb Mortal Wkly Rep 2009;58:749-752.

20711 Vaillant L, La Ruche G, Tarantola A, Barboza P: Epidemiology of fatal cases 208 associated with pandemic h1n1 influenza 2009. Euro Surveill 2009;14:pii=19309.

20912 van den Brand JM, Stittelaar KJ, van Amerongen G, Rimmelzwaan GF, Simon J, de 210 Wit E, Munster V, Bestebroer T, Fouchier RA, Kuiken T, Osterhaus AD: Severity of 211 pneumonia due to new h1n1 influenza virus in ferrets is intermediate between that due to 212 seasonal h1n1 virus and highly pathogenic avian influenza h5n1 virus. J Infect Dis 213 2010;201:993-999. 
21413 Morens DM, Taubenberger JK, Fauci AS: Predominant role of bacterial pneumonia as 215 a cause of death in pandemic influenza: Implications for pandemic influenza preparedness. J

216 Infect Dis 2008;198:962-970.

21714 Niffenegger JP: Proper handwashing promotes wellness in child care. J Pediatr Health 218 Care 1997;11:26-31.

21915 Roberts L, Smith W, Jorm L, Patel M, Douglas RM, McGilchrist C: Effect of infection 220 control measures on the frequency of upper respiratory infection in child care: A randomized, 221 controlled trial. Pediatrics 2000;105:738-742.

22216 Luby SP, Agboatwalla M, Feikin DR, Painter J, Billhimer W, Altaf A, Hoekstra RM: 223 Effect of handwashing on child health: A randomised controlled trial. Lancet 2005;366:225224233.

17 MacIntyre CR, Cauchemez S, Dwyer DE, Seale H, Cheung P, Browne G, Fasher M, Wood J, Gao Z, Booy R, Ferguson N: Face mask use and control of respiratory virus transmission in households. Emerg Infect Dis 2009;15:233-241. young adults: A randomized intervention trial. J Infect Dis;201:491-498.

23119 Cowling BJ, Fung RO, Cheng CK, Fang VJ, Chan KH, Seto WH, Yung R, Chiu B, 232 Lee P, Uyeki TM, Houck PM, Peiris JS, Leung GM: Preliminary findings of a randomized 233 trial of non-pharmaceutical interventions to prevent influenza transmission in households. 234 PLoS One 2008;3:e2101.

23520 Christenson B, Lundbergh P, Hedlund J, Ortqvist A: Effects of a large-scale 236 intervention with influenza and 23-valent pneumococcal vaccines in adults aged 65 years or 237 older: A prospective study. Lancet 2001;357:1008-1011.

23821 Kwong JC, Stukel TA, Lim J, McGeer AJ, Upshur RE, Johansen H, Sambell C, 239 Thompson WW, Thiruchelvam D, Marra F, Svenson LW, Manuel DG: The effect of universal 240 influenza immunization on mortality and health care use. PLoS Med 2008;5:e211.

24122 Nichol KL, Lind A, Margolis KL, Murdoch M, McFadden R, Hauge M, Magnan S, 242 Drake M: The effectiveness of vaccination against influenza in healthy, working adults. N 243 Engl J Med 1995;333:889-893.

24423 Nichol KL, Margolis KL, Wuorenma J, Von Sternberg T: The efficacy and cost 245 effectiveness of vaccination against influenza among elderly persons living in the community. $246 \quad$ N Engl J Med 1994;331:778-784.

24724 Nichol KL, Nordin J, Mullooly J, Lask R, Fillbrandt K, Iwane M: Influenza 248 vaccination and reduction in hospitalizations for cardiac disease and stroke among the elderly. 249 N Engl J Med 2003;348:1322-1332.

25025 Nichol KL, Nordin JD, Nelson DB, Mullooly JP, Hak E: Effectiveness of influenza 251 vaccine in the community-dwelling elderly. N Engl J Med 2007;357:1373-1381. 
25226 Reichert TA, Sugaya N, Fedson DS, Glezen WP, Simonsen L, Tashiro M: The 253 japanese experience with vaccinating schoolchildren against influenza. N Engl J Med 254 2001;344:889-896.

25527 Nougairede A, Lagier JC, Ninove L, Sartor C, Badiaga S, Botelho E, Brouqui P, 256 Zandotti C, De Lamballerie X, La Scola B, Drancourt M, Gould EA, Charrel RN, Raoult D: 257 Likely correlation between sources of information and acceptability of a/h1n1 swine-origin 258 influenza virus vaccine in marseille, france. PLoS One 2010;5:e11292.

25928 Herroelen L, de Keyser J, Ebinger G: Central-nervous-system demyelination after 260 immunisation with recombinant hepatitis b vaccine. Lancet 1991;338:1174-1175.

26129 Lee JW, Melgaard B, Clements CJ, Kane M, Mulholland EK, Olive JM: Autism, 262 inflammatory bowel disease, and mmr vaccine. Lancet 1998;351:905; author reply 908-909.

26330 Raoult D: Rapport sur le bioterrorisme. Ministère de la santé, de la famille et des 264 personnes handicapées France 2003 